\title{
Spermatogenic capacity in fertile men with elevated exposure to polychlorinated biphenyls
}

\section{Citation}

Petersen, M.S., J. Halling, P. Weihe, T.K. Jensen, P. Grandjean, F. Nielsen, and N. Jørgensen. 2015. "Spermatogenic Capacity in Fertile Men with Elevated Exposure to Polychlorinated Biphenyls." Environmental Research 138 (April): 345-351. doi:10.1016/j.envres.2015.02.030.

\section{Published Version}

doi:10.1016/j.envres.2015.02.030

\section{Permanent link}

http://nrs.harvard.edu/urn-3:HUL.InstRepos:34767891

\section{Terms of Use}

This article was downloaded from Harvard University's DASH repository, and is made available under the terms and conditions applicable to Other Posted Material, as set forth at http:// nrs.harvard.edu/urn-3:HUL.InstRepos:dash.current.terms-of-use\#LAA

\section{Share Your Story}

The Harvard community has made this article openly available.

Please share how this access benefits you. Submit a story.

\section{Accessibility}




\title{
Spermatogenic capacity in fertile men with elevated exposure to polychlorinated biphenyls
}

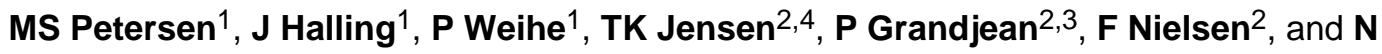 \\ Jørgensen 4
}

${ }^{1}$ Department of Occupational Medicine and Public Health, the Faroese Hospital System, Tórshavn, Faroe Islands ${ }^{2}$ Department of Environmental Medicine, University of Southern Denmark, Odense, Denmark ${ }^{3}$ Department of Environmental Health, Harvard School of Public Health, Boston, MA 02215, USA ${ }^{4}$ Rigshospitalet, University Department of Growth and Reproduction, Copenhagen, Denmark

\section{Abstract}

Background-Endocrine disrupting industrial chemicals, such as polychlorinated biphenyls (PCBs), are suspected to adversely affect male reproductive functions.

Objectives-The Faroe Islands community exhibits an unusually wide range of exposures to dietary contaminants, and in this setting we examined the possible association between PCB exposure and semen quality and reproductive hormones in fertile Faroese men.

Methods-Participants in this cross-sectional study include 266 proven fertile men residing in the Faroe Islands. PCB levels and hormone profiles were measured in serum samples taken at the clinical examination that included semen quality parameters.

Results-A significant positive association was seen between serum-PCB and the testosterone/ estradiol ratio $(\mathrm{p}=0.04)$. In the unadjusted analyses, elevated PCB exposure was associated with increased serum concentrations of SHBG $(\mathrm{p}=0.01)$ and FSH ( $\mathrm{p}=0.05)$. We found no association between the serum PCB concentration and the semen quality variables.

Conclusion-In this population of highly exposed fertile men, the current serum-PCB concentration was associated with higher androgen/estrogen ratio. Further studies are needed to

\footnotetext{
(C) 2015 Published by Elsevier Inc.

Corresponding author: Maria Skaalum Petersen, Department of Occupational Medicine and Public Health, the Faroese Hospital System, Sigmundargøta 5, Postbox 14, FO-110 Tórshavn, Faroe Islands, Tel: +298 316696; maria@ health.fo.

Publisher's Disclaimer: This is a PDF file of an unedited manuscript that has been accepted for publication. As a service to our customers we are providing this early version of the manuscript. The manuscript will undergo copyediting, typesetting, and review of the resulting proof before it is published in its final citable form. Please note that during the production process errors may be discovered which could affect the content, and all legal disclaimers that apply to the journal pertain.

Financial interests declaration:

The authors have no conflicts to declare.

The Ethical Review Committee of the Faroe Islands approved the study, and informed consent was obtained from each participating father.

Author's roles

Design of the study: PW, TKJ, NJ, PG. Execution of study: PW. Execution of exposure analyses: FN. Data preparation: MSP.

Statistical analysis: MSP. Interpretation of data: NJ, MSP, PG. First draft: MSP. Manuscript review, discussion and final approval: all.
} 
establish the findings and further document PCB-associated hormonal effects, any time windows of increased susceptibility, and the role of PCB in sub-fecundity.

\section{Keywords}

Semen quality; reproductive hormones; exposure; PCB; fertile men; Faroe Islands

\section{INTRODUCTION}

Semen quality studies of fertile men have been undertaken in several parts of the world (1-4) showing regional differences. For example, a European study of 1082 partners of pregnant women reported the lowest semen quality in Danish men, followed by French and Scottish men, while Finnish men had the best (1). Furthermore, studies of men from the general populations have shown that male sub-fecundity due to impaired semen quality is prevalent throughout Europe (5-10). A Faroese population-based study of 481 men showed low semen quality, around the same levels as Danish men (11). Although these descriptive studies have uncovered a prevalent sub-fecundity problem, the etiology is unclear and may include environmental chemicals. Endocrine disrupting industrial chemicals, such as polychlorinated biphenyls (PCBs), have been identified as a likely contributing factor (12-14). Recent experimental animal studies indicate that semen quality may be adversely affected by exposure during prenatal development as well as early postnatal life and even in adulthood (13-15). Epidemiological support is limited, as the most vulnerable time of exposure is unknown and may have occurred many years prior to the semen sampling (16). However, cross-sectional studies offer some support that increased body burdens of lipophilic pollutants, such as PCBs and the pesticide metabolite dichlorodiphenyldichloroethylene (p,p'-DDE), may be linked to abnormalities of human testicular function $(12,14,17)$.

Effects on semen quality may be mediated through interference with reproductive hormones. A subtle adverse effect on testicular function may be compensated by altered reproductive hormone stimulation of the testicles, and thus only reflected by altered levels of reproductive hormones necessary for spermatogenesis. Part of the reason for the apparent disagreement between studies may be that exposure parameters are measured at different time periods. Inclusion of subjects with high exposures and populations with wide exposure ranges is crucial to obtain sufficient statistical power to detect possible impact of pollutant exposures on semen quality. In this regard, the Faroe Islands is highly relevant, as an unusually wide range of pollutant exposures has been documented (18). Increased exposures to PCBs and DDE in this fishing community are mainly due to the consumption of blubber from the pilot whale, which accumulates persistent lipophilic substances present in marine pollution (Bloch et al., 1990). Of note, the use of pesticides and related substances is very limited in the Faroes as there is no formal farming and these substances are only used in limited extend in private households. Our previous study of $438 \mathrm{PCB}$-exposed adolescents revealed inverse associations with serum concentrations of both luteinizing hormone (LH) and testosterone and a positive association with the sex hormone binding globulin (SHBG), while associations with other hormones, testicular size and Tanner stage were uncertain (19).Of note, no semen samples were collected in that study. We examined the possible association 
between pollutant exposure and reproductive function parameters, including semen parameters, in a population of fertile Faroese males.

\section{MATERIALS AND METHODS}

\section{Study population}

During the period January 2007 to September 2008, pregnant Faroese women participated in a project focusing on associations between fertility and environment. The consenting women were asked for permission to contact their male partners. If she agreed the partner received an invitation by mail. For men who consented, an appointment for examination was arranged. All the women delivered a live born child. Participation included delivery of one semen sample, venous blood sampling, a physical examination, and completion of a questionnaire. A total of 376 women who participated in the study agreed to provide name and address of their partners, who were then invited to the semen study, and 282 men volunteered. Within this group, five men were excluded because the pregnancy had been achieved by fertility treatment; eight were non-Faroese, and three men were not able to produce a semen sample. Thus, 266 fertile men were included (71\% of all invited). The examination period for the men ranged from February 2009 to February 2010. Known diseases in reproductive organs or previous fertility treatments (not related to the current pregnancy) were recorded, but not considered exclusion criteria.

\section{Physical examination}

The men underwent a physical examination performed by one of two examiners. The examination included assessment of body weight and height, the Tanner stage of pubic hair, and any abnormalities of the penis, epididymis or testis including determination of the location of testis in scrotum. Testicular volumes were determined both by palpation using a Prader orchidometer (20).

\section{Questionnaire}

A questionnaire was generated in Faroese based on that used in Denmark in a study of partners of pregnant women $(1,21)$. The questionnaire included information on previous or current diseases, including any known history of fertility potential, time to pregnancy, some lifestyle factors like smoking and drinking habits. Questions on occupational exposure were not a part of the questionnaire, as occupational PCB exposure is not of concern in this population. The fathers filled in the questionnaire before the physical examination and responses were reviewed with the examining physician.

\section{Semen samples}

Semen samples were produced by masturbation, in most cases in a room next to the laboratory. However, five men produced the sample by masturbation at home and brought the samples to the laboratory within 30 minutes. The examining physician asked the men about ejaculation abstinence period. The semen sample was analyzed according to the World Health Organization 1999 guidelines (22) modified according results from a study of interobserver variation (23). Semen volume was estimated by weighing the collection tube with the semen sample and subtracting the weight of the empty pre-weighed tube, while 
assuming that $1 \mathrm{~mL}$ semen equals $1 \mathrm{~g}$. For sperm motility assessment, $10 \mu \mathrm{L}$ of well-mixed semen was placed on a clean glass slide kept at $37^{\circ} \mathrm{C}$ and covered with a $22 \times 22 \mathrm{~mm}$ coverslip. The preparation was placed on the heated stage of a microscope at $37^{\circ} \mathrm{C}$ and immediately examined at $400 \times$ magnification. The spermatozoa were classified as progressive motile (WHO class A+B), local motile (WHO class C) or immotile (WHO class D). Sperm concentration was determined using a Bürker-Türk haemocytometer (Paul Marienfeld GmbH \& Co. KG, Lauda-Königshofen, Germany). Total sperm count (semen volume $\times$ sperm concentration) was calculated. One technician performed all analyses. Morphology slides were made, Papanicolaou stained and finally assessed according to "strict criteria" (24) at the University Department of Growth and Reproduction (Dept. of GR) at the National Hospital (Rigshospitalet, RH) in Denmark by another technician. Technicians had no access to the identity or any other information about the study subjects.

\section{Exposure assessment}

On the day of the examination, a venous blood sample was drawn from each participant and centrifuged (3000 g, $10 \mathrm{~min}$ ). Serum was subsequently separated and kept frozen at $-80{ }^{\circ} \mathrm{C}$ until it was analyzed. PCB concentrations in serum samples was determined at the University of Southern Denmark using solid-phase extraction, followed by dual column gas chromatographic analysis with micro-electron capture detection according to a method previously described $(25,26)$. The mono-ortho substituted congeners PCB 28, PCB 105, PCB 118 and PCB 156 and the di-ortho substituted PCB 52, PCB 101, PCB 153, PCB 138 and PCB 180, as well as other persistent compounds (p,p'-DDE, o,p'-DDT, $\mathrm{HCH}, \beta-\mathrm{HCH}$ ) were recorded.

Spiked quality control samples were included in each series of samples. The laboratory participates regularly and successfully in the German External Quality Assessment Programme (G-EQUAS) for serum PCB analyses, coordinated by the University of Erlangen-Nüremberg, Germany. The results were adjusted for total serum lipid content and reported as $\mu \mathrm{g}$ per gram lipid. The total lipid content was calculated according to Philips formula (27). The cholesterol and triglyceride content in serum was determined by a kit based routine analysis on a Konelab 20 Clinical Chemistry Analyzer (Thermo Fischer Scientific, Waltham, MA).

The PCB exposure was estimated as the sum of serum concentrations of the major PCB congeners 138, 153 and 180 multiplied by 2 (28). This approximation is used because it avoids problems with congener concentrations below the detection limit, and because previous studies in this population have shown that these three PCB congeners represent close to $50 \%$ of the total concentration of PCBs. The median limit of detection was 0.03 $\mu \mathrm{g} / \mathrm{L}$ (LOD) for all congeners, which, at a mean lipid concentration of $7.45 \mathrm{~g} / \mathrm{l}$, corresponds to $0.004 \mu \mathrm{g} / \mathrm{g}$ lipid. Non-detectable levels of PCB congeners were assumed to equal half the limit of detection, i.e. $0.002 \mu \mathrm{g} / \mathrm{g}$ lipid. In regard to the other persistent compounds analyzed, some were generally not detectable or occurred in very low concentrations and were therefore left out; only p,p'-DDE was present in all serum samples and was therefore included in the statistical analysis. 


\section{Reproductive hormone analysis}

Reproductive hormone levels were assessed at Dept. of GR, Rigshospitalet. Serum levels of follicle-stimulating hormone (FSH), luteinizing hormone (LH), and sex hormone-binding globulin (SHBG) were determined using a time-resolved immunofluorometric assay (Delfia; Wallac Oy, Turku, Finland). Testosterone (T) and estradiol (E) levels were determined using time-resolved fluoroimmunoassays (Delfia; Wallac Oy). Inhibin B level was determined by means of a specific 2-sided enzyme immunometric assay (Inhibin B Gen II; Beckman Coulter Ltd., High Wycombe, United Kingdom).

Intra- and interassay coefficients of variation for measurements of FSH and luteinizing hormone were $3 \%$ and $4.5 \%$, respectively. Coefficients of variation for testosterone and SHBG were $<8 \%$ and $<5 \%$ respectively. The intra-assay coefficients of variation for estradiol and inhibin B were $<4 \%$ and $<7 \%$, respectively, and the inter-assay coefficients of variation were $<4 \%$ and $<6 \%$, respectively. The hormones were all measured within same time period and in the same assay batches.

Free testosterone (FT) was calculated on the basis of the measured serum concentrations of total testosterone and SHBG using the method of Vermeulen et al. assuming a fixed albumin concentration of $0.62 \mathrm{mmol} / \mathrm{L}$ (29). In addition, the ratios inhibin $\mathrm{B} / \mathrm{FSH}$, total T/estradiol, total T/LH, and FT/LH were calculated.

\section{Statistics}

The main outcome variables were the semen variables and serum concentrations of reproductive hormones and hormone ratios. The key exposure variable was the concomitant sum of serum concentration of polychlorinated biphenyls (PCBs). We also evaluated the individual PCB congeners. The calculated $\mathrm{PCB}$ was initially divided into quartiles or as a continuous logarithmic transformed variable. Logarithmic transformation was used to approach a normal distribution and reduce the relative impact of some very high PCB concentrations. Standard statistics (median, standard deviation (SD), $5^{\text {th }}-95^{\text {th }}$ percentiles and frequencies) were used for basic descriptions.

First we evaluated differences in PCB exposures according to characteristics of the men. Between-group differences were tested with non-parametric tests (Mann Whitney or Kruskal-Wallis) and correlations between the PCB congeners tested by Spearman correlation.

Differences in semen variables and reproductive hormone levels between the four PCB quartiles, the lowest compared with the highest quartile, and as continuous variable were then tested by linear regression, first unadjusted and then adjusted for confounders; sperm concentration, volume and total sperm count were adjusted for period of ejaculation abstinence in days, motility was adjusted for duration from ejaculation to assessment while the reproductive hormones were adjusted for body mass index as continuous variable, smoking (yes/no), age and hour of day of blood sampling. All covariates were included in the regression analyses for all hormones except for FSH and LH where the hour of day was not included. Using wet weight PCB concentrations with serum lipids included as a 
covariate in the model did not materially change the p-values and thus lipid-adjusted exposure values are used throughout.

In the regression analyses, sperm concentration, semen volume and total sperm count were transformed by cubic root to approach normality of the residuals. The percentages of motile spermatozoa were logit-transformed. Percentages of morphologically normal spermatozoa were close to normally distributed and entered the model untransformed. Reproductive hormone levels were transformed by the use of the natural logarithmic.

P-values below 5\% (two-tailed) were considered statistically significant. Analyses were performed using PASW GradPack 19.0 (SPSS Inc., Chicago, IL, USA).

\section{RESULTS}

A total of 266 men with mean age of 34.8 years participated. Major descriptive parameters for the study population stratified according to serum levels of PCBs are summarized in Table I, comparing all four quartiles and comparing the highest and lowest quartile. This information is based on questionnaire information and the physical examination. Overall, there was no difference in the physical appearance and previous history of health between the men with the highest and the lowest exposure, except for age that was higher in men with the highest PCB exposure and more men that had previously fathered a child in the highest PCB exposure group (Table I). The median $\mathrm{PCB}$ was $1.7 \mu \mathrm{g} / \mathrm{g}$ lipid $\left(5^{\text {th }}-95^{\text {th }}\right.$ percentile 0.3-7.0). The results of the serum analyses of the PCB congeners, along with the \PCB and related substances are shown in supplementary table I. All PCB congeners were highly correlated. Participants and non-participants were similar with respect to age, age of partner, area of residence, education, previous family history of congenital anomalies and previous children with congenital anomalies and time to pregnancy (data not shown).

In total, $92 \%$ of the men had a mean testicular volume above $15 \mathrm{~mL}$, and testicular size was positively associated with sperm concentration $(\mathrm{p}=0.01)$, total sperm count $(\mathrm{p}=0.003)$ and borderline associated with motility $(\mathrm{p}=0.08)$. Soft testicles in $2.2 \%$ of the men were associated with decreased sperm concentration $(\mathrm{p}=0.03)$ and motility $(\mathrm{p}=0.05)$. A total of $98.5 \%$ had both testicles in scrotum, and $98.9 \%$ had adult pubic hair distribution (i.e. Tanner stage 5 or 6 ). Hydrocele was detected in $4.5 \%$. Varicocele was detected in $4.4 \%$ of the men and was associated with lower total sperm count $(\mathrm{p}=0.04)$. None of these findings were associated with $\mathrm{PCB}$, except for testicular consistency, where a higher $\mathrm{PCB}$ concentration was associated with soft testicles $(\mathrm{p}=0.03)$.

The semen variables did not differ according to the $\mathrm{PPCB}$ as summarized in Table II, even when comparing the highest exposed with the lowest exposed, although there was a tendency for a higher percentage of morphologically normal forms in the high PCB group. This tendency was apparent among all congeners and POPs except for PCB52, PCB156 and PCB180.

In Table III, the serum concentrations of reproductive hormones are summarized. When stratifying according to $\mathrm{PCCB}$ quartiles in the unadjusted analysis, FSH showed the highest values in the fourth quartile; this difference was supported by the unadjusted high versus 
low quartile analysis. Inhibin B concentrations did not show significant differences between the four quartiles, although lower values were observed in the fourth quartile when compared with the first quartile. Concordantly, inhibin B/FSH levels tended to be lower in the fourth quartile compared with the first quartile. Unadjusted analyses showed a significant positive association between $\mathrm{PCB}$ and SHBG in all analyses.

In the adjusted analysis, the association between the $\mathrm{PCB}$ and the reproductive hormones was most pronounced for testosterone/estradiol ratio where a significant positive association was seen with PCB levels, both when comparing the quartiles, highest versus lowest quartile and trend. For the other hormones and ratios, all associations were non-significant and diminished when adjusted for confounders. However, the associations between $\mathrm{PCB}$ concentrations and FSH, Inhibin B, inhibin B/FSH ratio and SHBG had the same tendency after confounder adjustment but became somewhat weaker.

All congeners and POPs were tested separately, but the associations were similar to those reported above (data not shown) and thus results are shown only for $\mathrm{PPCB}$. Among the major congeners, PCB180 and PCB156 showed higher regression coefficients for positive association with FSH, SHBG and testosterone/estradiol ratio and negative with the inhibin $\mathrm{B} / \mathrm{FSH}$ ratio.

\section{DISCUSSION}

This is the first study of semen quality and reproductive hormones among fertile men with high PCB exposure. PCB exposure was significantly positively associated with testosterone/ estradiol ratio, a finding not reported earlier to our knowledge. This might be a chance finding, which would be supported by the fact that we did not see any association between calculated free testosterone/estradiol ratio and PCB exposures. However, one animal study with female mice showed significantly elevated testosterone/estradiol ratio after exposure to several halogenated organic compounds, though not after PCB153 exposure (30), suggesting an inhibition on the aromatase activity (a CYP19 enzyme) that controls the androgen/ estrogen ratio (31).

A positive, borderline significant association was found between high PCB and SHBG among the Faroese fertile men. This finding should be interpreted with caution but is consistent with a study among Faroese 14-years old boys where increased SHBG levels were observed at higher PCB exposure (19) and with most studies of lower exposures (32-35); the median PCB153 levels ranging from from $42 \mathrm{ng} / \mathrm{g}$ lipid in US males (36) and $46 \mathrm{ng} / \mathrm{g}$ lipid in southern Norway (32) to highest levels in Swedish fishermen (190 ng/g lipid) (34) as compared to a median of $300 \mathrm{ng} / \mathrm{g}$ lipid in the fertile Faroese men.

The serum-SHBG concentrations in the Faroese fertile men were higher than among Danish fertile men as was the median LH and estradiol concentrations, which could contribute to the increase in SHBG. Furthermore, both the total testosterone and calculated free-testosterone tended to be lower (37). Thus, the endocrine profile of the average Faroese male indicates a reduced Leydig cell capacity. Due to our study design we cannot document causations. However, experimental in vivo studies have shown that exposure to PCBs disrupts Leydig 
cellular function in adult rats (38-40), and exposing lactating rats to Aroclor 1242 caused significant adverse effects on Leydig cell function, reducing the capacity to produce testosterone in response to LH stimulation in adult male offspring (41). Furthermore, SHBG is produced by the liver, and PCBs are known to affect a variety of liver functions (42) and it could be speculated that PCB-induced hepatic SHBG synthesis could play a possible role, although this possibility remains to be substantiated. Thus, it is plausible that PCB hepatotoxicity may contribute to the increased serum-SHBG concentrations. Of note, unadjusted results may not represent causal associations (due to confounding by the adjustment factors) but as similar tendencies are observed in two groups of randomly selected young Faroese men (unpublished results) the observed associations are deemed reliable.

No association was found between serum PCB concentration and the semen quality parameters. Still, the fertile Faroese men tended to have low semen quality, even when compared with Danes, which also was seen among young unselected Faroese men (11). This effect could be due to the fact that di-ortho substituted biphenyls (e.g. PCB138, PCB153 and PCB180) possess the ability to interfere with sexual hormone regulated processes (43). In addition, the men were fertile and therefore have proven fertility thus maybe less susceptible to the adverse effects of PCB.

None of the other POPs examined in the present study (e.g., DDE) had any detectable effect on reproductive hormones in spite of the fact that they are lipophilic substances that comigrate with PCBs and may have anti-androgen effects (44). However, apart from DDE, serum concentrations of these POPs are not as highly elevated among the Faroese population as are the PCBs.

An association between previous paternity and high PCBs exposure was observed but the explanation might be that men in highest PCB group were older and thus more likely to have fathered children.

The study had many advantages, one being carrying out the study in a very homogeneous, quite big group of fertile men and another being the analysis of many PCB congeners, both mono-ortho and di-ortho substituted congeners. Many previous studies have only used PCB153 as exposure marker (32-35). None of the associations we observed for $\mathrm{PCB}$ were present for PCB-153 alone and would therefore have been missed had we focused only on this congener. As the POPs migrate together and are as reflections of a mixed PCB exposure that had varied over time, epidemiological studies are unable to distinguish between actions of single congeners and other related contaminants. In an observational study, exposures are not a matter of design, and the interrelationships between multiple congeners often prevent conclusions whether one congener is of greater importance than other. Thus in our opinion is that the sum of major PCB congener concentrations better reflects the overall PCB mixture exposure, as the three congeners did not involve problems with the detection limit. One of the limitations in this study is that we did not analyze for co-planar dioxin-like PCB and thus do not have full information on the dioxin-like activity on the hormones. However, a previous study showed that dioxin exposure in the Faroes is not higher than northern European levels (28). In addition, our study was cross-sectional and reverse causation 
cannot be excluded, however PCBs have long half-lives and it is therefore unlikely. The participation rate is quite high compared with other population studies of semen quality and selection bias could be suspected with higher participation of men who had experienced fertility problems or had a long time to pregnancy. However, all men had become fathers before recruitment, and no significant differences were found between participating and non-participating fathers, thus indicating limited influence of selection bias.

\section{CONCLUSIONS}

In this population of highly exposed fertile men, the current serum-PCB concentration was associated with higher androgen/estrogen ratio. The clinical relevance of this finding is unknown and needs to be verified in other studies. Further do the results indicate that the current serum-PCB concentration adversely affects the hepatic SHBG production.

Prospective epidemiological studies are needed to further document PCB-associated effects, any time windows of increased susceptibility, and the role of PCB in sub-fecundity.

\section{Supplementary Material}

Refer to Web version on PubMed Central for supplementary material.

\section{Acknowledgments}

The authors would like to thank all the participating fathers. Further we want to thank Kaj Kallsberg, MD, for performing some of the physical examinations and the laboratory technicians Lindu Kannuberg and Annu Louisu Jacobsen for performing the semen analyses. Also, thanks to nurse Nanna Kallsberg for her hard work in recruiting the fathers.

Funding

This study was supported by the National Institute of Environmental Health Sciences, NIH (ES014460) and the European Commission through its Sixth Framework Programme for RTD (contract no. FOOD-CT-2006-016253, PHIME). The authors are solely responsible for all results and conclusions, which do not necessarily reflect the position of any of the funding agencies.

\section{REFERENCES}

1. Jorgensen N, Andersen AG, Eustache F, Irvine DS, Suominen J, Petersen JH, et al. Regional differences in semen quality in Europe. Human reproduction (Oxford, England). 2001; 16(5):10129.

2. Swan SH, Brazil C, Drobnis EZ, Liu F, Kruse RL, Hatch M, et al. Geographic differences in semen quality of fertile U.S. males. Environ Health Perspect. 2003; 111(4):414-20. [PubMed: 12676592]

3. Iwamoto T, Nozawa S, Yoshiike M, Namiki M, Koh E, Kanaya J, et al. Semen quality of fertile Japanese men: a cross-sectional population-based study of 792 men. BMJ open. 2013; 3(1)

4. Gao J, Gao ES, Walker M, Yang Q, Wu JQ, Zhu QX, et al. Reference values of semen parameters for healthy Chinese men. Urologia internationalis. 2008; 81(3):256-62. [PubMed: 18931539]

5. Jorgensen N, Joensen UN, Jensen TK, Jensen MB, Almstrup K, Olesen IA, et al. Human semen quality in the new millennium: a prospective cross-sectional population-based study of 4867 men. BMJ open. 2012; 2(4)

6. Paasch U, Salzbrunn A, Glander HJ, Plambeck K, Salzbrunn H, Grunewald S, et al. Semen quality in sub-fertile range for a significant proportion of young men from the general German population: a co-ordinated, controlled study of 791 men from Hamburg and Leipzig. International journal of andrology. 2008; 31(2):93-102. [PubMed: 18315714] 
7. Jorgensen N, Vierula M, Jacobsen R, Pukkala E, Perheentupa A, Virtanen HE, et al. Recent adverse trends in semen quality and testis cancer incidence among Finnish men. International journal of andrology. 2011; 34(4 Pt 2):e37-48. [PubMed: 21366607]

8. Punab M, Zilaitiene B, Jorgensen N, Horte A, Matulevicius V, Peetsalu A, et al. Regional differences in semen qualities in the Baltic region. International journal of andrology. 2002; 25(4): 243-52. [PubMed: 12121574]

9. Fernandez MF, Duran I, Olea N, Avivar C, Vierula M, Toppari J, et al. Semen quality and reproductive hormone levels in men from Southern Spain. International journal of andrology. 2012; 35(1):1-10. [PubMed: 21332503]

10. Axelsson J, Rylander L, Rignell-Hydbom A, Giwercman A. No secular trend over the last decade in sperm counts among Swedish men from the general population. Human reproduction (Oxford, England). 2011; 26(5):1012-6.

11. Halling J, Petersen MS, Jorgensen N, Jensen TK, Grandjean P, Weihe P. Semen quality and reproductive hormones in Faroese men: a cross-sectional population-based study of 481 men. BMJ open. 2013; 3(3)

12. Meeker JD, Hauser R. Exposure to polychlorinated biphenyls (PCBs) and male reproduction. Systems biology in reproductive medicine. 2010; 56(2):122-31. [PubMed: 20377311]

13. Sharpe RM. Environmental/lifestyle effects on spermatogenesis. Philosophical transactions of the Royal Society of London Series B, Biological sciences. 2010; 365(1546):1697-712.

14. Vested A, Giwercman A, Bonde JP, Toft G. Persistent organic pollutants and male reproductive health. Asian journal of andrology. 2014; 16(1):71-80. [PubMed: 24369135]

15. Dickerson SM, Cunningham SL, Gore AC. Prenatal PCBs disrupt early neuroendocrine development of the rat hypothalamus. Toxicol Appl Pharmacol. 2011; 252(1):36-46. [PubMed: 21277884]

16. Skakkebaek NE. Testicular dysgenesis syndrome. Hormone research. 2003; 60(Suppl 3):49. [PubMed: 14671395]

17. Cai J, Wang C, Wu T, Moreno JM, Zhong Y, Huang X, et al. Disruption of spermatogenesis and differential regulation of testicular estrogen receptor expression in mice after polychlorinated biphenyl exposure. Toxicology. 2011; 287(1-3):21-8. [PubMed: 21664404]

18. Weihe P, Grandjean P, Debes F, White R. Health implications for Faroe islanders of heavy metals and PCBs from pilot whales. The Science of the total environment. 1996; 186(1-2):141-8. [PubMed: 8685706]

19. Grandjean P, Gronlund C, Kjaer IM, Jensen TK, Sorensen N, Andersson AM, et al. Reproductive hormone profile and pubertal development in 14-year-old boys prenatally exposed to polychlorinated biphenyls. Reproductive toxicology (Elmsford, NY). 2012; 34(4):498-503.

20. Lenz S, Giwercman A, Elsborg A, Cohr KH, Jelnes JE, Carlsen E, et al. Ultrasonic testicular texture and size in 444 men from the general population: correlation to semen quality. European urology. 1993; 24(2):231-8. [PubMed: 8104150]

21. Jensen TK, Slama R, Ducot B, Suominen J, Cawood EH, Andersen AG, et al. Regional differences in waiting time to pregnancy among fertile couples from four European cities. Human reproduction (Oxford, England). 2001; 16(12):2697-704.

22. World Health Organization W. Laboratory maual for examination of human semen and semencervicl mucus interaction. 4th ed.. Cambridge University Press; New York: 1999.

23. Jorgensen N, Auger J, Giwercman A, Irvine DS, Jensen TK, Jouannet P, et al. Semen analysis performed by different laboratory teams: an intervariation study. International journal of andrology. 1997; 20(4):201-8. [PubMed: 9401822]

24. Menkveld R, Stander FS, Kotze TJ, Kruger TF, van Zyl JA. The evaluation of morphological characteristics of human spermatozoa according to stricter criteria. Human reproduction (Oxford, England). 1990; 5(5):586-92.

25. Petersen MS, Halling J, Damkier P, Nielsen F, Grandjean P, Weihe P, et al. Caffeine N3demethylation (CYP1A2) in a population with an increased exposure to polychlorinated biphenyls. European journal of clinical pharmacology. 2006; 62(12):1041-8. [PubMed: 17089110] 
26. Grandjean P, Weihe P, Nielsen F, Heinzow B, Debes F, Budtz-Jorgensen E. Neurobehavioral deficits at age 7 years associated with prenatal exposure to toxicants from maternal seafood diet. Neurotoxicology and teratology. 2012; 34(4):466-72. [PubMed: 22705177]

27. Phillips DL, Pirkle JL, Burse VW, Bernert JT Jr. Henderson LO, Needham LL. Chlorinated hydrocarbon levels in human serum: effects of fasting and feeding. Archives of environmental contamination and toxicology. 1989; 18(4):495-500. [PubMed: 2505694]

28. Grandjean P, Weihe P, Needham LL, Burse VW, Patterson DG Jr. Sampson EJ, et al. Relation of a seafood diet to mercury, selenium, arsenic, and polychlorinated biphenyl and other organochlorine concentrations in human milk. Environmental research. 1995; 71(1):29-38. [PubMed: 8757236]

29. Vermeulen A, Verdonck L, Kaufman JM. A critical evaluation of simple methods for the estimation of free testosterone in serum. The Journal of clinical endocrinology and metabolism. 1999; 84(10):3666-72. [PubMed: 10523012]

30. Maranghi F, Tassinari R, Moracci G, Altieri I, Rasinger JD, Carroll TS, et al. Dietary exposure of juvenile female mice to polyhalogenated seafood contaminants (HBCD, BDE-47, PCB-153, TCDD): comparative assessment of effects in potential target tissues. Food and chemical toxicology: an international journal published for the British Industrial Biological Research Association. 2013; 56:443-9. [PubMed: 23500779]

31. Canton RF, Scholten DE, Marsh G, de Jong PC, van den Berg M. Inhibition of human placental aromatase activity by hydroxylated polybrominated diphenyl ethers (OH-PBDEs). Toxicol Appl Pharmacol. 2008; 227(1):68-75. [PubMed: 18022659]

32. Haugen TB, Tefre T, Malm G, Jonsson BA, Rylander L, Hagmar L, et al. Differences in serum levels of CB-153 and p,p'-DDE, and reproductive parameters between men living south and north in Norway. Reprod Toxicol. 2011; 32(3):261-7. [PubMed: 21736938]

33. Bonde JP, Toft G, Rylander L, Rignell-Hydbom A, Giwercman A, Spano M, et al. Fertility and markers of male reproductive function in Inuit and European populations spanning large contrasts in blood levels of persistent organochlorines. Environ Health Perspect. 2008; 116(3):269-77. [PubMed: 18335090]

34. Giwercman AH, Rignell-Hydbom A, Toft G, Rylander L, Hagmar L, Lindh C, et al. Reproductive hormone levels in men exposed to persistent organohalogen pollutants: a study of inuit and three European cohorts. Environ Health Perspect. 2006; 114(9):1348-53. [PubMed: 16966087]

35. Richthoff J, Rylander L, Jonsson BA, Akesson H, Hagmar L, Nilsson-Ehle P, et al. Serum levels of $2,2^{\prime}, 4,4^{\prime}, 5,5^{\prime}$-hexachlorobiphenyl (CB-153) in relation to markers of reproductive function in young males from the general Swedish population. Environ Health Perspect. 2003; 111(4):409-13. [PubMed: 12676591]

36. Ferguson KK, Hauser R, Altshul L, Meeker JD. Serum concentrations of p, p'-DDE, HCB, PCBs and reproductive hormones among men of reproductive age. Reprod Toxicol. 2012; 34(3):429-35. [PubMed: 22564984]

37. Andersson AM, Jorgensen N, Frydelund-Larsen L, Rajpert-De Meyts E, Skakkebaek NE. Impaired Leydig cell function in infertile men: a study of 357 idiopathic infertile men and 318 proven fertile controls. The Journal of clinical endocrinology and metabolism. 2004; 89(7):3161-7. [PubMed: 15240588]

38. Murugesan P, Balaganesh M, Balasubramanian K, Arunakaran J. Effects of polychlorinated biphenyl (Aroclor 1254) on steroidogenesis and antioxidant system in cultured adult rat Leydig cells. The Journal of endocrinology. 2007; 192(2):325-38. [PubMed: 17283232]

39. Kovacevic R, Vojinovic-Miloradov M, Teodorovic I, Andric S. Effect of PCBs on androgen production by suspension of adult rat Leydig cells in vitro. The Journal of steroid biochemistry and molecular biology. 1995; 52(6):595-7. [PubMed: 7779764]

40. Murugesan P, Kanagaraj P, Yuvaraj S, Balasubramanian K, Aruldhas MM, Arunakaran J. The inhibitory effects of polychlorinated biphenyl Aroclor 1254 on Leydig cell LH receptors, steroidogenic enzymes and antioxidant enzymes in adult rats. Reproductive toxicology (Elmsford, NY). 2005; 20(1):117-26.

41. Kim IS, Ariyaratne HB, Chamindrani Mendis-Handagama SM. Effects of continuous and intermittent exposure of lactating mothers to aroclor 1242 on testicular steroidogenic function in the adult male offspring. Tissue \& cell. 2001; 33(2):169-77. [PubMed: 11392670] 
42. EFSA. European Food Safety Authority. Opinion of the scientific panel on contaminants in the food chain on a request from the Commission related to the presence of non-dioxin-like polychlorinated biphenyls (PCB) in feed and food. The EFSA Journal. 2005:1-137.

43. Bonefeld-Jorgensen EC, Andersen HR, Rasmussen TH, Vinggaard AM. Effect of highly bioaccumulated polychlorinated biphenyl congeners on estrogen and androgen receptor activity. Toxicology. 2001; 158(3):141-53. [PubMed: 11275356]

44. Gray LE Jr. Wilson VS, Stoker T, Lambright C, Furr J, Noriega N, et al. Adverse effects of environmental antiandrogens and androgens on reproductive development in mammals. International journal of andrology. 2006; 29(1):96-104. discussion 5-8. [PubMed: 16466529] 


\section{Highlights}

- Cross-sectional study including 266 proven fertile men residing in the Faroe Islands.

- Assessing the effect of persistent pollutants on semen parameters and reproductive hormones.

- A significant positive association was found between serum-PCB and the testosterone/estradiol ratio.

- No association was found between the serum PCB concentration and the semen quality variables. 


\section{Table I}

Physical appearance and self-reported information of Faroese fertile men stratified according to serum levels of $\sum$ PCBs. Results shown are medians $\left(5-95^{\text {th }}\right.$ percentile) or percentages $(\%)$.

\begin{tabular}{|c|c|c|c|c|c|c|c|}
\hline & \multirow{2}{*}{$\begin{array}{l}\text { All men } \\
n=266\end{array}$} & \multicolumn{4}{|c|}{ Quartiles } & \multicolumn{2}{|c|}{ P value } \\
\hline & & First $(n=65)$ & Second $(n=67)$ & Third $(n=66)$ & Fourth $(n=66)$ & Quartiles & High vs. low \\
\hline $\begin{array}{l}\text { Exposure } \sum \mathrm{PCB}(\mu \mathrm{g} / \mathrm{g} \\
\text { lipid) }\end{array}$ & $1.7(0.3-7.0)$ & $0.6(0.2-0.9)$ & $1.2(0.9-1.7)$ & $2.2(1.8-2.8)$ & $3.9(2.9-9.8)$ & $<0.0005^{*}$ & $<0.0005^{*}$ \\
\hline \multicolumn{8}{|l|}{ Physical appearance } \\
\hline Age (years) & $34.8(24.5-45.1)$ & $31.2(24.3-42.8)$ & $32.7(21.9-44.7)$ & $34.8(28.6-44.9)$ & $37.5(28.3-47.1)$ & $<0.0005^{*}$ & $<0.0005^{*}$ \\
\hline Height (cm) & $181(171-192)$ & $181(169-192)$ & $180(172-191)$ & $182(170-192)$ & $179(171-193)$ & 0.8 & 0.9 \\
\hline Weight (kg) & $85.2(68.0-113.0)$ & $84.5(68.4-118.4)$ & $85.4(64.2-112.8)$ & $85.7(66.6-113.8)$ & $85.2(65.6-107.1)$ & 0.9 & 0.9 \\
\hline BMI (kg/m2) & $26.0(21.2-33.3)$ & $25.5(21.5-37.2)$ & $26.3(21.1-33.4)$ & $26.0(21.3-32.9)$ & $26.2(20.1-33.2)$ & 0.9 & 0.9 \\
\hline Testicular size $(\mathrm{mL})^{a}$ & $23(15-28)$ & $22.5(15.0-27.6)$ & $23.5(15.0-27.4)$ & $22.5(15.0-28.0)$ & $23.5(17.2-29.3)$ & 0.8 & 0.6 \\
\hline \multicolumn{8}{|l|}{ Lifestyle } \\
\hline Alcohol per week (units) & $3.0(0-17.8)$ & $2.8(0-19.4)$ & $3.4(0-16.7)$ & $3.0(0-32.8)$ & $4.0(0-22.9)$ & 0.8 & 0.4 \\
\hline Currentsmoker & 40 & 43 & 33 & 39 & 44 & 0.6 & 0.9 \\
\hline $\begin{array}{l}\text { Mother smoked during } \\
\text { pregnancy }\end{array}$ & 33 & 43 & 30 & 26 & 33 & 0.4 & 0.3 \\
\hline Taking medication $b$ & 20 & 27 & 17 & 17 & 20 & 0.5 & 0.4 \\
\hline $\begin{array}{l}\text { Been treated for }{ }^{c} \\
\text { Cryptorchidism }\end{array}$ & 2 & 3 & 2 & 0 & 2 & 0.6 & 0.8 \\
\hline \multicolumn{8}{|l|}{ Been diagnosed as having $d$} \\
\hline Cryptorchidism & 8 & 10 & 8 & 6 & 6 & 0.9 & 0.5 \\
\hline Hypospadias & 0.4 & 0 & 0 & 0 & 2 & 0.4 & 0.3 \\
\hline Sexual transmitted disease ${ }^{g}$ & 14 & 14 & & & 11 & 0.9 & 0.8 \\
\hline Phimosis & 15 & 18 & 16 & 17 & 11 & 0.7 & 0.3 \\
\hline Varicocele & 3 & 2 & 3 & 5 & 3 & 0.8 & 0.6 \\
\hline Testicularcancer & 1 & 0 & 2 & 2 & 0 & 0.6 & 1.0 \\
\hline \multicolumn{8}{|l|}{ Other $^{e}$} \\
\hline Previously fathered a child & 66 & 53 & 66 & 71 & 73 & 0.09 & $0.02^{*}$ \\
\hline Current pregnancy planned & 71 & 73 & 78 & 70 & 69 & 0.6 & 0.4 \\
\hline Current TTP & $3.0(1.0-36.0)$ & $3.0(1-46.2)$ & $3.0(1.0-36.0)$ & $3.0(1.0-63.0)$ & $2.0(0.6-36.0)$ & 0.8 & 0.5 \\
\hline $\begin{array}{l}\text { Ever had TTP over } 6 \\
\text { months }\end{array}$ & 18 & 13 & 23 & 17 & 20 & 0.5 & 0.3 \\
\hline
\end{tabular}

Abbreviation: PCB, polychlorinated biphenyls; $\ \mathrm{PCB}=(\mathrm{PCB} 138+\mathrm{PCB} 153+\mathrm{PCB} 180) * 2$; TP, Time to pregnancy;

* significant at 0.05 level

$a_{\text {Testes size (palpatoric, mean of both testes) }}$

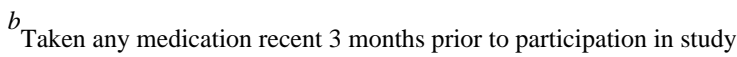

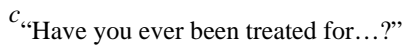

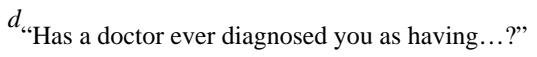

Environ Res. Author manuscript; available in PMC 2016 April 01. 
eHave you ever...?"

$f_{\text {Hormonal, surgical or combination }}$

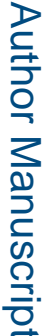

${ }^{g}$ Chlamydia, gonorrhea, warts or herpes 


\section{Table II}

Semen variables of Faroese fertile men stratified according to serum levels of एPCBs. Results shown are medians $\left(5-95^{\text {th }}\right.$ percentile).

\begin{tabular}{|c|c|c|c|c|c|c|c|c|}
\hline & \multirow{2}{*}{$\begin{array}{c}\text { All men } \\
\mathrm{n}=266\end{array}$} & \multicolumn{4}{|c|}{ Quartiles } & \multicolumn{3}{|c|}{ Unadjusted/adjusted $P$ values } \\
\hline & & First $(n=65)$ & Second $(n=67)$ & Third $(n=66)$ & Fourth $(n=66)$ & Quartiles & High vs. low & Trend \\
\hline Semen volume $(\mathrm{mL})^{a}$ & $4.0(1.7-8.2)$ & $4.1(1.6-10.6)$ & $3.9(2.0-9.1)$ & $4.0(1.6-7.3)$ & $3.8(1.6-9.0)$ & $0.4 / 0.5$ & $0.4 / 0.3$ & $0.4 / 0.6$ \\
\hline Sperm concentration (mill/mL) ${ }^{a}$ & $47(8-188)$ & $41(8-178)$ & $47(7-154)$ & $50(8-194)$ & $48(9-212)$ & $0.2 / 0.4$ & $0.3 / 0.4$ & $0.8 / 0.5$ \\
\hline Total sperm count (mill) ${ }^{a}$ & $182(28-710)$ & $161(40-176)$ & $178(27-639)$ & $186(28-870)$ & $208(18-786)$ & $0.3 / 0.5$ & $0.5 / 0.7$ & $0.7 / 0.5$ \\
\hline Normal morphology (\%) & $7.5(1.0-16.5)$ & $7.0(0.4-17.0)$ & $6.8(1.1-15.6)$ & $7.5(1.2-16.5)$ & $8.5(1.2-16.9)$ & 0.1 & 0.2 & 0.07 \\
\hline Motile sperm $(\%)^{b}$ & $71(48-84)$ & $71(45-86)$ & $71(49-86)$ & $70(44-84)$ & $72(53-83)$ & $0.9 / 0.8$ & $0.7 / 0.9$ & $0.3 / 0.3$ \\
\hline Period of abstinence (days) & $4.0(2.0-4.0)$ & $4.0(2.0-4.0)$ & $4.0(2.1-4.0)$ & $4.0(3.0-4.0)$ & $3.0(2.0-4.0)$ & 0.4 & 0.5 & 0.4 \\
\hline
\end{tabular}

Abbreviation: PCB, polychlorinated biphenyls; $\mathrm{PCCB}=(\mathrm{PCB} 138+\mathrm{PCB} 153+\mathrm{PCB} 180) * 2 ; \mathrm{h}$, hour

${ }^{a}$ Adjusted for period of abstinence in days

${ }^{b}$ Adjusted for duration from ejaculation to assessment 


\section{Table III}

Reproductive hormone levels in Faroese fertile men stratified according to serum levels of एPCBs. Results shown are medians $\left(5-95^{\text {th }}\right.$ percentile)

\begin{tabular}{|c|c|c|c|c|c|c|c|c|}
\hline & \multirow{2}{*}{$\begin{array}{l}\text { All group } \\
\text { n=266 }\end{array}$} & \multicolumn{4}{|c|}{ Quartiles } & \multicolumn{3}{|c|}{ Unadjusted/adjusted p value } \\
\hline & & First $(n=65)$ & Second $(n=67)$ & Third (n=66) & Fourth $(n=66)$ & Quartiles & High vs. Low & \\
\hline FSH (IU/L) & $3.3(1.3-7.9)$ & $3.0(1.1-6.8)$ & $3.3(1.6-8.0)$ & $3.1(1.1-7.2)$ & $3.9(1.3-8.2)$ & $0.06 / 0.49$ & $0.05 * / 0.08$ & \\
\hline Inhibin B (pg/mL) & $213(116-354)$ & $219(111-380)$ & $212(116-350)$ & $214(125-319)$ & $210(106-384)$ & $0.14 / 0.6$ & $0.5 / 0.73$ & 0 . \\
\hline Inhibin $\mathrm{B} / \mathrm{FSH}$ & $62(17.8-251.5)$ & $66.8(22.3-257.4)$ & $60.2(14.1-240.3)$ & $70.4(18.8-262.6)$ & $52.0(15.0-276.3)$ & $0.05 * 0.43$ & $0.09 / 0.17$ & 0 . \\
\hline LH (IU/L) & $3.8(1.7-7.3)$ & $3.9(1.8-7.4)$ & $3.8(1.1-7.4)$ & $3.6(1.7-7.5)$ & $3.8(1.8-7.6)$ & $0.51 / 0.39$ & $0.43 / 0.34$ & 0 . \\
\hline Testosterone (nmol/L) & $18(10-31)$ & $18(11-30)$ & $17(10-34)$ & $18(9-29)$ & $19(10-32)$ & $0.19 / 0.35$ & $0.43 / 0.22$ & 0 . \\
\hline Free Testosterone $(\mathrm{pmol} / \mathrm{L})$ & $333(175-527)$ & $365(171-553)$ & $332(189-577)$ & $318(171-507)$ & $344(180-556)$ & $0.62 / 0.97$ & $0.31 / 0.63$ & 0. \\
\hline Estradiol (nmol/L) & $76(50-116)$ & $82(51-119)$ & $73(51-122)$ & $78(48-117)$ & $76(48-115)$ & $0.85 / 0.22$ & $0.28 / 0.32$ & 0 . \\
\hline SHBG (nmol/L) & $39(18-70)$ & $38(16-66)$ & $35(17-65)$ & $38(18-71)$ & $43(25-85)$ & $0.01 * / 0.11$ & $0.02 * / 0.16$ & 0.0 \\
\hline Testosterone/LH & $4.6(2.0-10.9)$ & $5.0(2.2-10.6)$ & $4.2(1.8-14.3)$ & $4.7(1.8-11.1)$ & $4.7(2.1-9.9)$ & $0.77 / 0.99$ & $0.90 / 0.86$ & 0 \\
\hline Free testosteron/LH & $90(37-189)$ & $93(44-172)$ & $91(35-268)$ & $87(36-188)$ & $88(39-185)$ & $0.37 / 0.5$ & $0.18 / 0.71$ & 0. \\
\hline Testosterone/estradiol & $228(137-386)$ & $218(125-395)$ & $223(115-284)$ & $216(138-372)$ & $250(140-392)$ & $0.22 / 0.04^{*}$ & $0.11 / 0.04^{*}$ & 0.2 \\
\hline Free Testosterone/estradiol & $4.4(2.7-6.5)$ & $4.5(2.8-6.6)$ & $4.5(2.4-6.7)$ & $4.1(2.8-6.6)$ & $4.6(2.6-6.5)$ & $0.49 / 0.25$ & $0.92 / 0.15$ & 0 . \\
\hline Time of blood sampling & $10: 00(8: 30-13: 30)$ & $10: 00(8: 30-13: 52)$ & $9: 30(8: 30-13: 17)$ & 10:00 (9:00-13.54) & $10: 00(8: 40-13: 30)$ & 0.2 & 0.5 & \\
\hline
\end{tabular}

Abbreviation: PCB, polychlorinated biphenyls; $\mathrm{PPCB}=(\mathrm{PCB} 138+\mathrm{PCB} 153+\mathrm{PCB} 180) * 2 ; \mathrm{FSH}$, follicle-stimulating hormone; LH, luteinizing hormone; SHBG, sex hormone-binding globulin

${ }^{a}$ Adjusted for age at examination, BMI in groups, current smoking and time of sampling. LH and FSH not for time of sampling * significant at 0.05 level 